\title{
Workplace Communication Hindrances: The Contextual, Structural and Behavioural Factors
}

Susanna Bithiah Varma, Nur Sherina Zainal Abidin, Norhafizah Amir, Ira Syaqira Sukimin, Hana Nadia Nadri, Noor Hanim Rahmat

To Link this Article: http://dx.doi.org/10.6007/IJARBSS/v11-i9/11015 DOI:10.6007/IJARBSS/v11-i9/11015

Received: 21 July 2021, Revised: 26 August 2021, Accepted: 08 September 2021

Published Online: 29 September 2021

In-Text Citation: (Varma et al., 2021)

To Cite this Article: Varma, S. B., Abidin, N. S. Z., Amir, N., Sukimin, I. S., Nadri, H. N., \& Rahmat, N. H. (2021). Workplace Communication Hindrances: The Contextual, Structural and Behavioural Factors. International Journal of Academic Research in Business and Social Sciences, 11(9), 1844-1855.

Copyright: (c) 2021 The Author(s)

Published by Human Resource Management Academic Research Society (www.hrmars.com) This article is published under the Creative Commons Attribution (CC BY 4.0) license. Anyone may reproduce, distribute, translate and create derivative works of this article (for both commercial and non-commercial purposes), subject to full attribution to the original publication and authors. The full terms of this license may be seen at: http://creativecommons.org/licences/by/4.0/legalcode

Vol. 11, No. 9, 2021, Pg. 1844 - 1855

Full Terms \& Conditions of access and use can be found at http://hrmars.com/index.php/pages/detail/publication-ethics 


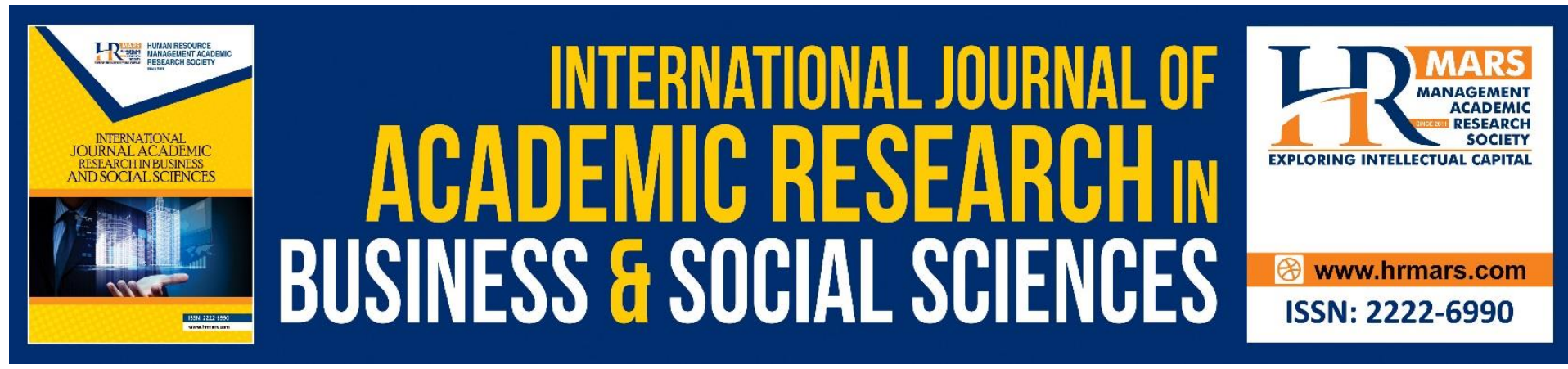

\title{
Workplace Communication Hindrances: The Contextual, Structural and Behavioural Factors
}

\author{
Susanna Bithiah Varma ${ }^{1}$, Nur Sherina Zainal Abidin², \\ Norhafizah Amir ${ }^{3}$, Ira Syaqira Sukimin', \\ Hana Nadia Nadri ${ }^{5}$, Noor Hanim Rahmat ${ }^{6}$ \\ 1,2,3,4Akademi Pengajian Bahasa, Universiti Teknologi MARA Cawangan Johor, Kampus
} Segamat, Johor Darul Ta'zim, Malaysia, ${ }^{5}$ Akademi Pengajian Bahasa, Universiti Teknologi MARA, Shah Alam, Selangor, Malaysia, ${ }^{6}$ Akademi Pengajian Bahasa, Universiti Teknologi MARA Cawangan Johor, Kampus Pasir Gudang, Johor Darul Ta'zim, Malaysia

\section{Abstract}

The workplace is where a variety of people meet to fulfil the needs of the organisation. The meeting of various people from many backgrounds can often cause communication failure. This hinders productivity and work efficiency. It can also cause detrimental injuries within the workplace by evoking anger, misinterpretations, cynicism, loss of trust and respect resulting in an unhealthy workplace atmosphere. Consequently, all these rippling effects distorts the progress and growth of a workplace which could negatively impact its founded visions and future achievements to ruins. Without us realizing, communication is the most minute yet key course of action that takes place in conveying information, resolving a conflict to achieve an agreement, and having mutual understanding among employees to establish high quality relationships in the workplace. Evidently, a successful organization may crumble due to factors that could have been early detected and avoided in their communication. Therefore, this pilot study aims to investigate factors that can hinder communication at the workplace. A total number of 148 participants responded to a survey which focused on contextual factors in terms of verbal and non-verbal communication, structural factors such as the environment, and behavioural factors such as personal barriers. The findings reveal that contextual, structural, and behavioural factors are potential hindrances to successful communication at the workplace of communicators who are unaware of their actions while interacting. Hence, employers should induce efforts to eliminate communication barriers at the workplace to allow information to be conveyed excellently. Besides that, employers need to provide a good work environment that facilitates effective communication. Employers should also take measures to allow employees to socialize to reduce the personal barriers among them.

Keywords: Communication Barriers, Contextual, Structural, Behavioural, Workplace

\section{Introduction}

\section{Background of Study}

One of the most fundamental success factors of an efficient functioning workplace lies in the strength of its communication. Communication is the course of action that takes place in 
conveying information, resolving a conflict to achieve an agreement, and having mutual understanding among employees to establish high quality relationships in the workplace (Adu-Oppong \& Agyin-Birikorang, 2014). Successful workplace communication is crucial to be practiced and maintained otherwise misunderstandings may occur causing a communication barrier. Breakdowns in communication not only distorts the growth and progress of a workplace, it also causes anger, misinterpretations, cynicism, loss of trust and respect resulting in an unhealthy workplace atmosphere (Sadia et al., 2018; Rana, 2013). According to Yusof and Rahmat (2020), some barriers of communication are identified to be language, environmental and personal barriers.

\section{Statement of Problem}

To achieve goals, effective communication at a prime level is required in the organization, but confusion can be the result of failure in communication. In various aspects of a proper functioning organization, effective communication is essential. Communication is the exchange of meaning, and an effective two-way communication becomes even more difficult when there is a language barrier (Adler, 1991; Rabbani et al., 2017). Effective communication can be the result of the effective method's continuous evaluation and the development of a plan for communication practice for the departments of the institution (higher education institution) through cooperation with other members of the organization.

Beauty (2013) stated that inefficient communication results in poor relationships with staff of the organization and it means that the objectives are not being met in the organization and that its development objectives are not being met. At universities, communication problems are occurring as well. Andrade (2017) said, "One of the major difficulties in the communication between the head of department and academic staff is overlapping layers of communication; sometimes the information that has been conveyed by the head of the department is subsequently disseminated by other individuals in the organization." For instance, education institutes are regulated quite differently, their operative style, on both virtual and ground layouts, endless evaluations are required by these organizations and effective communication is in need to build a relationship that is effective with individuals and at team level (Sharma, 2015). Various folks who have the motley achievement and are from very diverse backgrounds are handled by universities. To be an effective, advanced, and healthy form of communication is vital, as in organization they transfer not only the information but also their impact or consequences on communication staff along with its effectiveness. Hence, this study acts as a medium to investigate hindrance to workplace communication.

\section{Objective and Research Questions}

The objective of this study is to investigate how contextual, structural, and behavioural factors hinder workplace communication. This study is done to answer the following questions:

1. How do Contextual factors become hindrance to workplace communication?

2. How do Structural factors become hindrance to communication?

3. How is Behavioural factor a hindrance to workplace communication? 


\section{Literature Review \\ Factors Affecting Communication}

There are several factors that can affect communication at the workplace. Kheirandish, Avilagh, and Nazemi (2017) identified three communication barriers at the workplace. The fist factor is (a) contextual elements and they refer to the cultural, technical, and communicative environment. The second factor is (b) structural elements. They refer to the complexity, the formality, inflexibility, and centralization of the communication. The last factor is (c) behavioural elements and they refer to perceptual and human barriers.

\section{Past Studies}

We live in a culturally diverse world. People will encounter individuals from different races and religions that are using different language in their daily encounters as the world is turning into a global village. Foreigners are a considerable growing segment in the workplace. A study by Madera, Dawson, \& Neal (2014) examines the influence of managers' communication satisfaction with limited English-speaking employees. One survey was done by 130 hotels and lodging managers. The results depicted that contentment along the value of communication with limited English-speaking employees also decreased role ambiguity and role conflicts which led to lower turnover intentions. Another study by Tiwari (2015) with the purpose to explore the significance of non-verbal communication in maintaining the longevity and effectiveness of interpersonal relationships. The study deals with the definition of nonverbal communication, the forms, and types, how to interpret them, and also some tips on how to enhance these non-verbal communications.

Stans, Dalemans, de Witte, Smeets, and Beursken (2017) conducted a study to investigate the role of the physical environment in communication between health-care professionals and persons with communication problems is a neglected area. The study focuses on factors in the physical environment and how they play a role in written communication. Sixteen publications were analysed. Findings revealed that there are 6 factors in conversation between people who are communication vulnerable and health-care professional, and the factors are: (1) humidness and temperature, (2) setting and placement of furniture, (3) lighting, (4) acoustic environment, (5) convenience of augmentative and alternative communication, and (6) written knowledge.

Behavioural obstacles such as perceptual barriers impede workplace communication. A case study by Kheirandish et. al (2017) performed on 567 people comprising employees, managers, and supervisors of the National Iranian Oil Company analyzed behavioral factors such as enthusiasm, self-esteem, and job fulfilment. The authors employed a descriptive, survey method of research whereby a researcher-made questionnaire was used as the instrument. The Kolmogorov-Smirnov test, F-test and T-test were used to examine the results which depicted that perceptual barrier prevent communication from flowing effectively. The study therefore suggested the elimination of behavioral obstacles by upholding tolerance in communication, discouraging biasness neither in favor of or against co-workers, practicing religious teachings to avoid halo effects such as prejudgment and prejudice, and empathizing with co-worker's emotions.

Besides that, personal human barriers such as differences in characteristics of emotion or interpretation, may increase misunderstandings thus decreasing effective communication. $A$ 
study by Gut et. al. (2017) examines the personal opinions and experiences of 20 white-collar Chinese employees in a global European manufacturing company to analyze their communication barriers in a multicultural environment. A questionnaire survey was designed to assemble data from a socio-cultural and psycho-cultural point of view. The results depicted that 'disrespecting and stereotyping employees with a different cultural background' caused communication breakdowns. Therefore, to enhance a positive attitude in communication among co-workers, the study emphasized that efforts towards culture-driven factors should be given weight as they influence decision-making, negotiation skills, job satisfaction and decrease of work absence.

\section{Conceptual Framework of the Study}

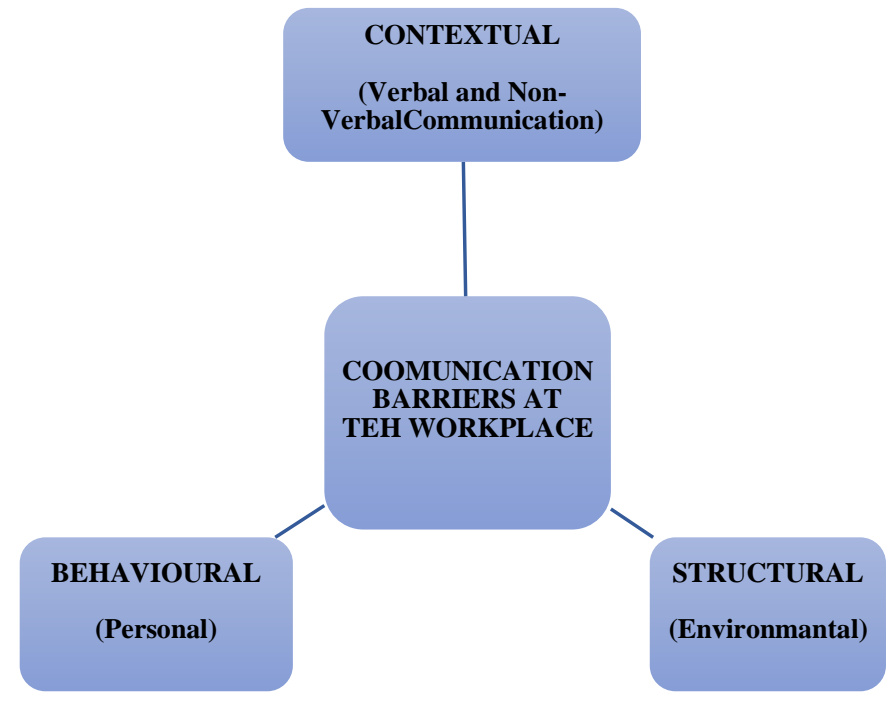

Figure 1- Conceptual Framework of the Study

Source: Kheirandish, Avilagh, and Nazemi (2017) \& Yusof and Rahmat (2020)

The theoretical framework is presented in Figure 1. It is based on communication barriers by Kheirandish, Avilagh, and Nazemi (2017) and they reported that three factors can cause communication barriers (contextual, structural, and behavioural). In the context of this study, verbal and non-verbal communication at the workplace can be contextual barriers. Next, the environmental factors at the workplace are also considered as structural barriers. Finally, personal factors can acta $s$ behavioural barriers to the employees.

\section{Methodology}

\section{Research Design}

This quantitative pilot study is done to explore factors that hinder workplace communication. 148 participants responded to the instrument. They come from various industries. The instrument used is a survey adapted from Kheirandish, Avilagh, and Nazemi (2017) and Yusof and Rahmat (2020). Cronbach analysis showed a score of $\alpha=.690$ (refer table 1). Data is collected via google form and analysed using SPSS version 26 to reveal percentages for demographic profile and mean score for variables. 


\begin{tabular}{|c|c|}
\hline \multicolumn{2}{|c|}{ Reliability Statistics } \\
\hline $\begin{array}{l}\text { Cronbach's } \\
\text { Alpha }\end{array}$ & $\mathrm{N}$ of Items \\
\hline .690 & 17 \\
\hline
\end{tabular}

Table1- Reliability Statistics for the Study

\section{Findings}

\section{Findings for Demographic Profile}

Q2 Age Group

\begin{tabular}{|l|l|l|}
\hline 1 & $18-29$ & $20.9 \%$ \\
\hline 2 & 20 to 29 years old & $0 \%$ \\
\hline 3 & 30 to 39 years old & $43.2 \%$ \\
\hline 4 & 40 to 49 years old & $14.9 \%$ \\
\hline 5 & 50 to 59 years old & $19.6 \%$ \\
\hline 6 & 60 above & $1.4 \%$ \\
\hline
\end{tabular}

Table 2- Percentage for Age Group

Table 2 above shows the age group the participants are in. The highest percentage of the age group in this study is 30 to 39 years old which is $43.2 \%$. The second highest age group is 18 to 29 years old recorded at $20.9 \%$. It is then followed by the age group of participants between 50 to 59 years old at $19.6 \%$. The percentage of participants from the 40 to 49 years old is recorded at the second lowest which is $14.9 \%$. The lowest percentage of industry for this study are from the age group 60 years and above at $1.4 \%$.

Q3. Highest Academic Level

\begin{tabular}{|l|l|l|}
\hline 1 & SPM & $4.1 \%$ \\
\hline & STPM & $1.4 \%$ \\
\hline 2 & Diploma & $5.4 \%$ \\
\hline 3 & Degree & $52.7 \%$ \\
\hline 4 & Master & $33.1 \%$ \\
\hline 5 & Phd & $3.4 \%$ \\
\hline
\end{tabular}

Table 3- Percentage for Highest Academic Level

Table 3 above shows the academic level the participants are in. The highest percentage of the academic level in this study is degree which is $52.7 \%$. The second highest academic level is Master recorded at $33.1 \%$. It is then followed by the academic level of Diploma at $5.4 \%$. Next, the participants with an academic level of SPM are recorded at $4.1 \%$. The percentage of participants from Phd is recorded at the second lowest which is $3.4 \%$. The lowest percentage of academic level for this study is from STPM at $1.4 \%$. 
Q4 Type of Industry

\begin{tabular}{|c|c|c|}
\hline 1 & Agricultural, Forestry and Fishing & $2 \%$ \\
\hline 2 & Mining & $0 \%$ \\
\hline 3 & Construction & $4.7 \%$ \\
\hline 4 & Manufacturing & $4.1 \%$ \\
\hline 5 & Transportation \& Public Utilities & $2 \%$ \\
\hline 6 & Wholesale Trade & $1.4 \%$ \\
\hline 7 & Retail Trade & $10.8 \%$ \\
\hline 8 & Finance, Insurance and Real Estate & $9.5 \%$ \\
\hline 9 & Public Services \& Administration & $2.7 \%$ \\
\hline 10 & Health Services & $4.7 \%$ \\
\hline 11 & Food \& Beverage & $2.7 \%$ \\
\hline 12 & Oil \& Gas & $4.1 \%$ \\
\hline 13 & Information Technology & $10.8 \%$ \\
\hline 14 & Education & $29.1 \%$ \\
\hline 15 & Housewife & $1.4 \%$ \\
\hline 16 & $\begin{array}{l}\text { Others (Retail trade, Wholesale Trade, Energy, Engineering, } \\
\text { Automobile, Business Processing Outsourcing, } \\
\text { Telecommunication, Insurance, Banking, Branding and } \\
\text { Marketing, Lawyer, Internet, Travel and HR) }\end{array}$ & $10.0 \%$ \\
\hline
\end{tabular}

Table 4- Percentage for Industry

Table 4 shows the type of industry the participants are in, the highest percentage of the industry for this study is education which is $29.1 \%$. The second highest percentage comes from both travel and lodging as well as information technology at $10.8 \%$. It is then followed by other industries such as retail trade, wholesale trade, energy, engineering, automobile, business processing outsourcing, Telecommunication, insurance, banking, branding, and marketing, lawyer, internet, travel and human resource at $10 \%$. Next, the percentage of finance, insurance and real estate industry is recorded at 9.5\%. Both percentage for construction and health services are $4.7 \%$ and followed by oil and gas industry and manufacturing at $4.1 \%$ respectively. The table also shows the participants for food and beverage and public services and administration industries are recorded at $2.7 \%$. Next it can be seen that the percentage of participants from agricultural, forestry and fishing as well as transportation and public utilities is recorded at only $2 \%$ and makes them the third lowest percentage of industry. Next, we have engineering services and housewife as the second lowest industries which are only $1.4 \%$ and the lowest for this study is from mining which is $0 \%$.

\section{Findings for Contextual Factors}

According to Kheirandish, Avilagh, and Nazemi (2017), contextual factors can be described in the form of verbal and non-verbal communication (Yusof and Rahmat, 2020). Findings are presented in terms of (a) verbal and (b) non-verbal communication. 


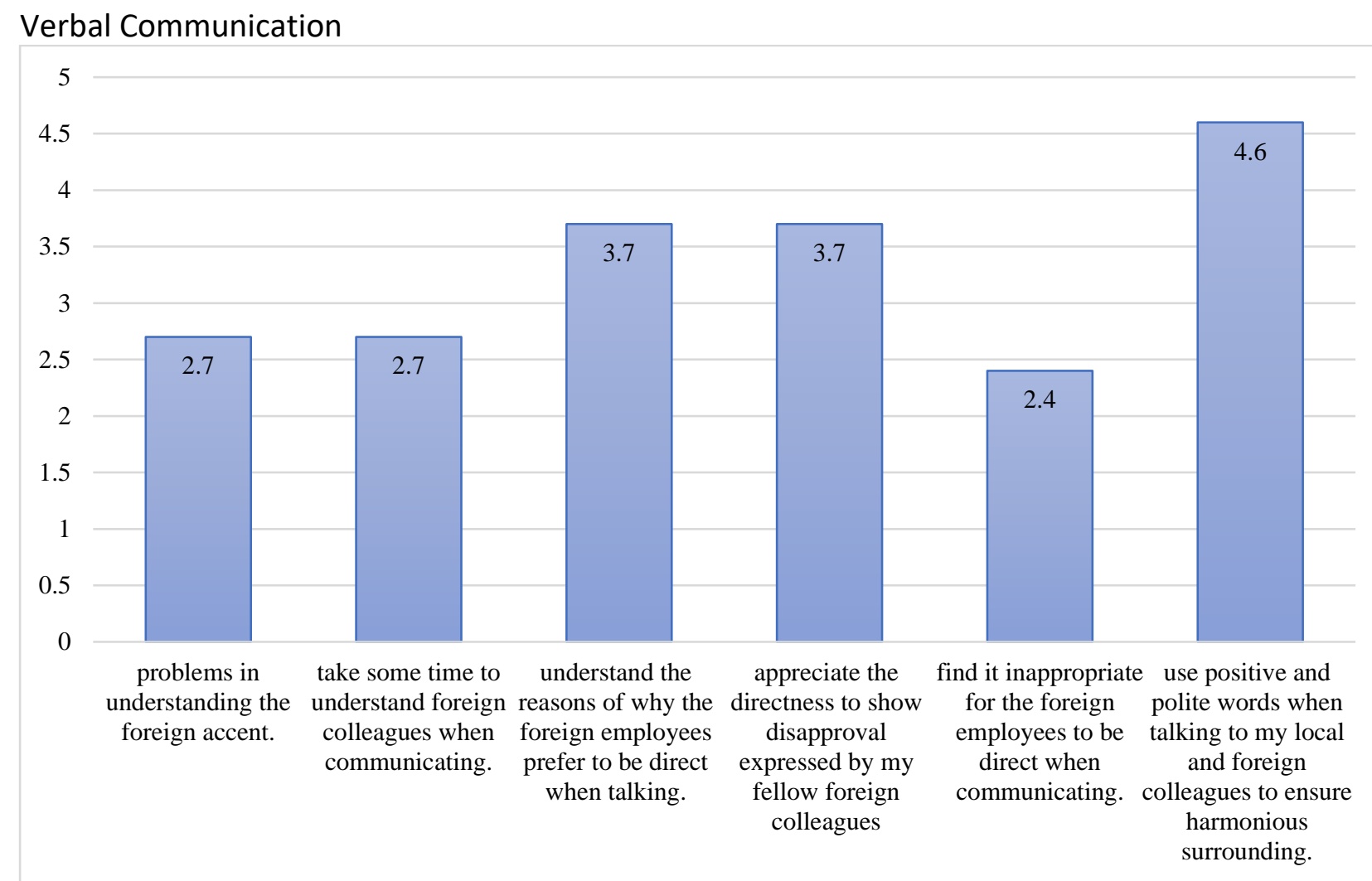

Figure 2- Mean for Verbal Communication

Figure 2 above shows the responses about verbal communication in the workplace. It can be clearly seen that the respondents always use positive and polite words when they are talking to either local or foreign colleagues to ensure harmonious surroundings with the highest mean for this category (4.6). Next, the second highest mean for verbal communication (3.7) are respondents who understand the reasons why foreign employees prefer to be direct when talking and respondents appreciate directness to show disapproval expressed by their foreign colleagues. With the mean 2.7, the respondents agree with the statement they have problems understanding the foreign accent and they take some time to understand their colleagues when communicating. The lowest mean for this category is at 2.4 for the respondents who find it inappropriate for the foreign employees to be direct when communicating. 


\section{Non-Verbal}

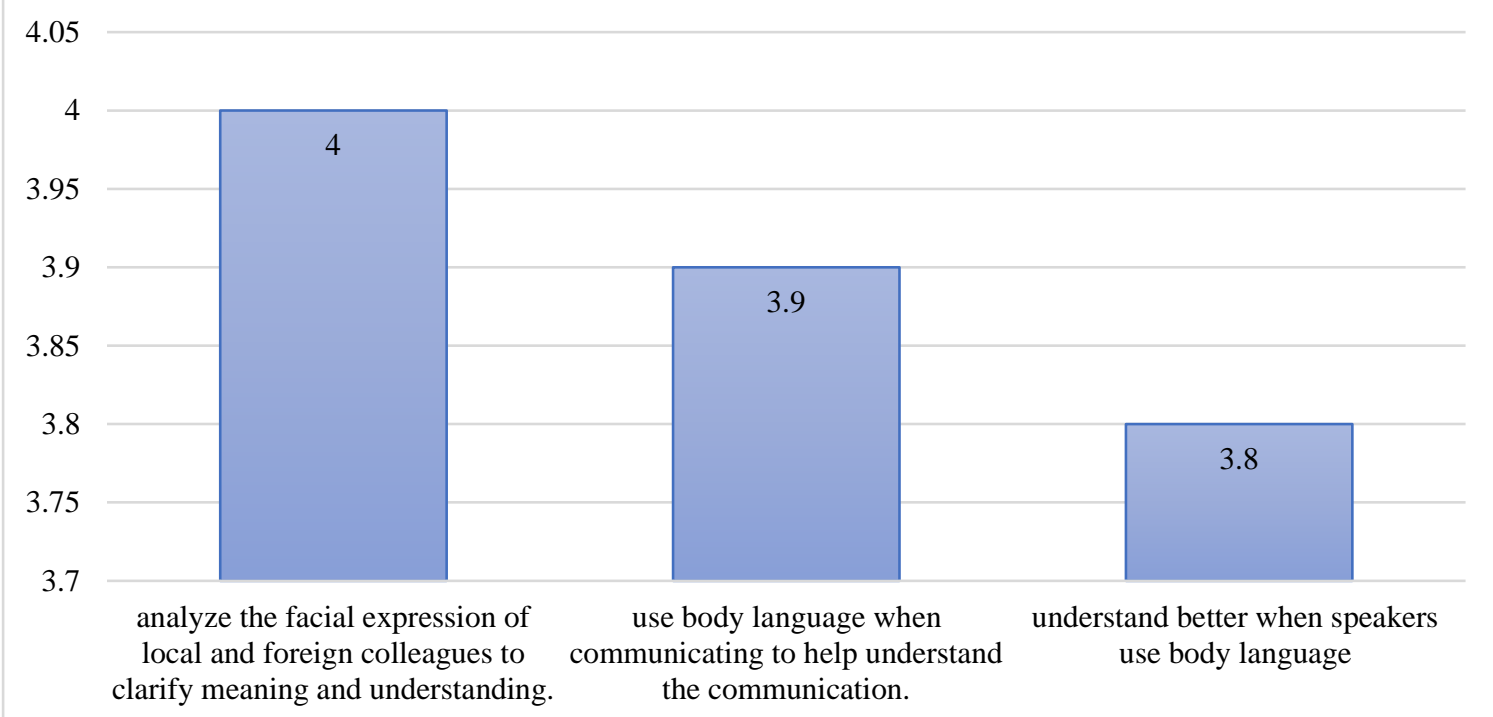

Figure 3- mean for Non-Verbal Communication

Figure 3 above shows the mean for non-verbal communication. Respondents "analysed the facial expression of their local and foreign colleagues to clarify meaning and understanding" (4). Findings also showed that respondents "used body language when communicating" (3.9) and they "understood better when speakers used body language" (3.8).

\section{Findings for Structural factors}

The structural factor by Kheirandish, Avilagh, and Nazemi (2017), is in line with environmental factors by Yusof and Rahmat (2020).

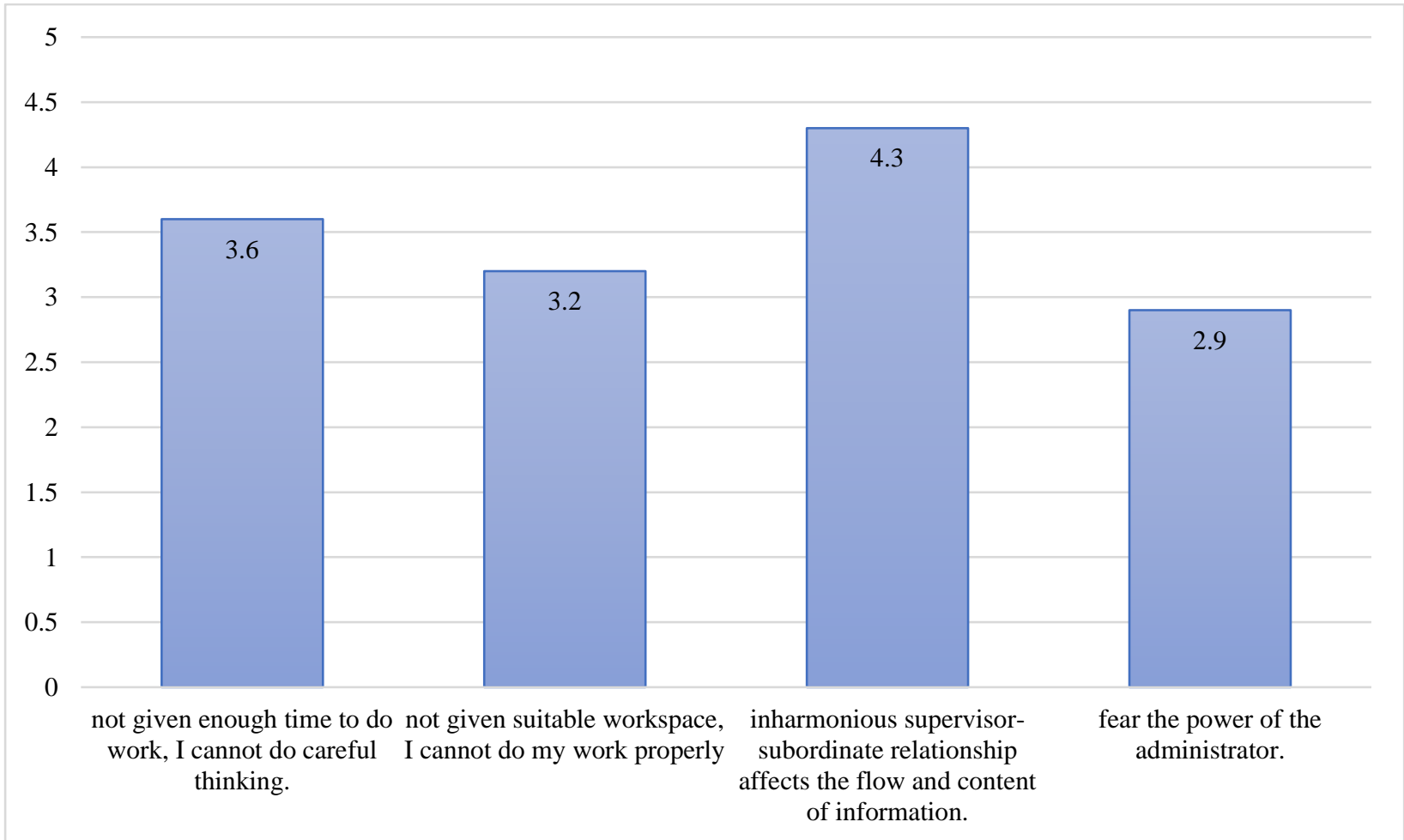

Figure 4- Mean for Structural (Environmental) Factors 
Figure 4 reveals the findings for environmental factors. Respondents reported that "the nonharmonious supervisor-subordinate relationship affects the flow and content of communication" (4.3). They also felt that if they "were not given enough time to work, they cannot do careful thinking" (3.6) and if they were nor "given suitable workspace, they cannot do their work properly" (3.2).

\section{Findings for Behavioural factors}

The structural factor by Kheirandish, Avilagh, and Nazemi (2017), is in line with personal factors by Yusof and Rahmat (2020).

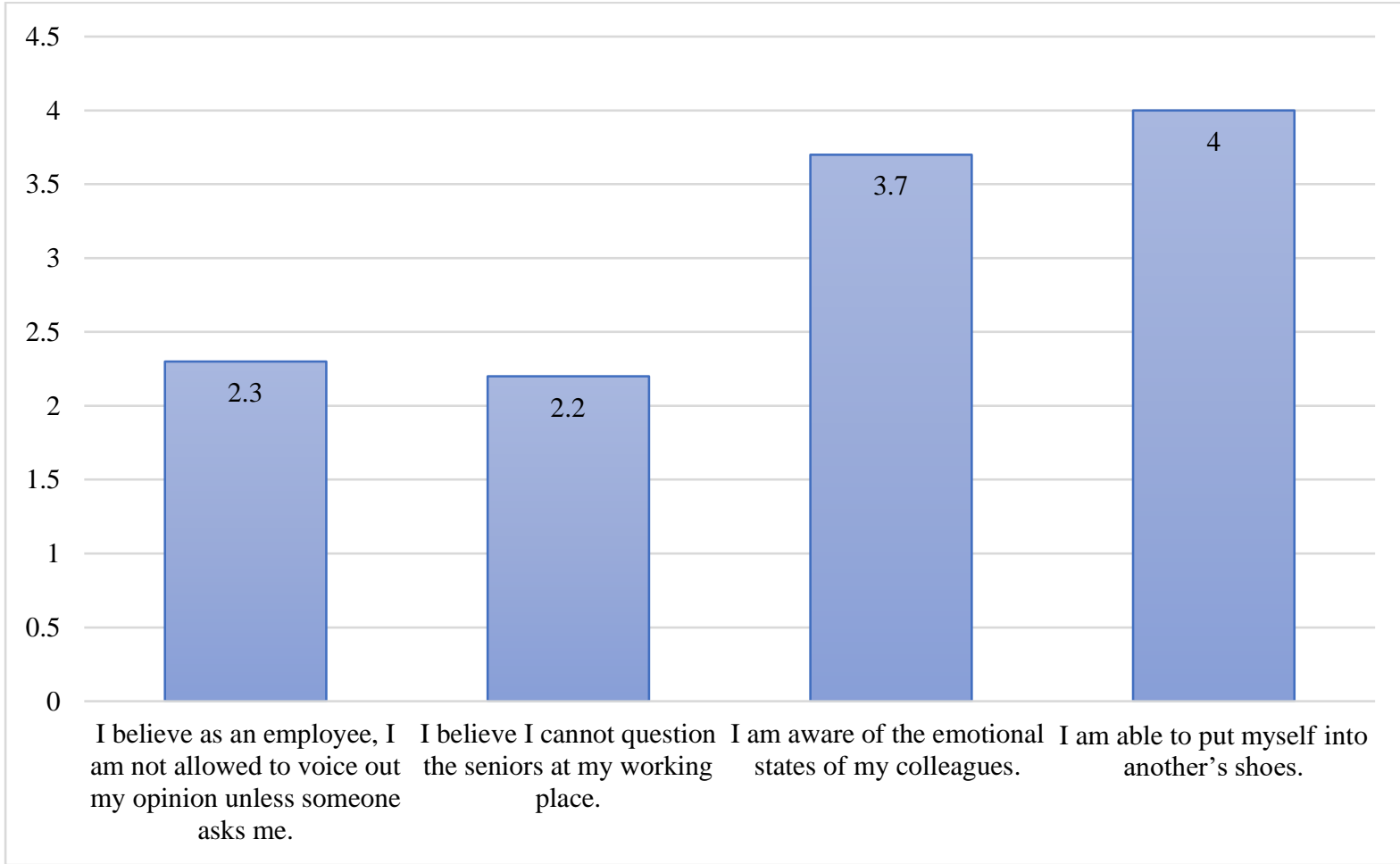

Figure 5- Mean for Personal Factors

With reference to figure 5 above, respondents felt they were "able to put themselves into another's shoes" (4). They were also "aware of the emotional states of his colleagues" (3.7).

\section{Conclusion}

\section{Summary of Findings and Discussion}

The findings for the first factor which are the contextual elements described as verbal and non-verbal communication in this study, depicted that it was inappropriate for the foreign employees to be direct when communicating. To avoid these barriers, the use of polite words is very important to maintain a harmonious workplace environment. The use of positive verbal communication is also a way to maintain good work relationships with foreign workers. This is also agreed by Madera, Dawson, \& Neal (2014) who found that good verbal communication helped give a good image to the company. Besides verbal communication, the use of appropriate non-verbal communication can also reduce barriers to communication among people at the workplace. Tiwari (2015) also reported on the proper use of non-verbal communication to avoid barriers to communication. 
Kheirandish, Avilagh, and Nazemi (2017) referred to the environmental barrier as structural. This is because the structure of where the communication takes can either facilitate or hinder understanding. The findings of the second factor reveal that "the non-harmonious supervisorsubordinate relationship affects the flow and content of communication". They also felt that if they "were not given enough time to work, they cannot do careful thinking" and if they were nor "given suitable workspace, they cannot do their work properly". This proves that the surrounding environment plays an important role to facilitate or hinder communication at the workplace. This includes getting enough time in a conducive work environment.

The last factor which are behavioural elements refer to perceptual and human barriers.

Behavioural such as personal factors can also facilitate or hinder communication among workers. Gut et. al. (2017) found that personal factors that either the speaker or the receiver have can often hinder or help communication.

\section{Implications}

Employers need to make efforts to reduce communication barriers at the workplace. Communication barriers need to be eliminated so that information can be conveyed successfully. Employers need to endure a good work environment to facilitate effective communication. Measures should be taken by the employers to allow employees to socialize to reduce the personal barriers among them. Future study could investigate more factors in communication barriers. It would be interesting to interview parties to explore deeper other communication barriers at the workplace.

\section{Reference}

Adu-Oppong, A. A., \& Agyin-Birikorang, E. (2014). Communication in the workplace: Guidelines for improving effectiveness. Global Journal of Commerce and Management Perspective, 3(5), 208-213. https://www.longdom.org/abstract/communication-in-theworkplace-guidelines-for-improving-effectiveness-2603.html

Tiwari, A. K. (2020). Non-verbal Communication- An Essence of Interpersonal Relationship at Workplace. Management Insight, Vol 11(2), 109-114. Retrieved from http://journals.smsvaranasi.com/index.php/managementinsight/article/view/431

Gut, A., Wilczewski, M., \& Gorbaniuk, O. (2017). Cultural differences, stereotypes and communication needs in intercultural communication in a global multicultural environment: The employees' perspective. Journal of Intercultural Communication, 43(1), 1-20. http://immi.se/intercultural/nr43/gorbaniuk.html

Madera, J. M, Dawson, M., Neal, J. A. (2014). Managing language barriers in the workplace: The role of job demands and resources on turnover intentions. International Journal of Hospitality Management, Vol 42, 117-125. Retrieved from https://doi.org/10.1016/j.ijhm.2014.06.004

Kheirandish, M., Avilagh, H. A., \& Nazemi, N. (2017). An empirical study of the pathology of organizational communications based on Three Branches Model: A case study. Arab Economic and Business Journal, 12(2), 81-92. https://doi.org/10.1016/j.aebj.2017.10.001

Rabbani, M., Farrokhi-Asl, H., \& Manavizadeh, N. (2017). Using Robust-DEA optimization approach to analyze performance and efficiency of a mine in north of Iran. Management Science Letters, 7(2), 97-110. Retrieved from http://dx.doi.org/10.5267/j.msl.2016.11.009. 
Rana, R. (2013). Effective communication in a diverse workplace. International Journal of Enhanced Research in Management and Computer Applications, 2(2). https://ssrn.com/abstract=2225761.

Sadia, A., Salleh, B. M., Zulida, A. K., \& Sazuliana, A. (2018). Investigating hindrance to effective communication between the management and academic staff of universities in Malaysia: A qualitative case study. International Journal of Education and Psychological Research, 7(2), 1-4. http://ijepr.org/paper.php?id=424

Sharma, P. R. (2015) "Organizational Communication: Perceptions of Staff Members' Level of Communication Satisfaction and Job Satisfaction" Electronic Theses and Dissertations. Paper 2481. Retrieved from https://dc.etsu.edu/etd/2481.

Stans, S. E. A., Dalemans, R. J. O., de Witte, L. P, Smeets, H. W. H., \& Beursken, A. J. (2017) The Role of the Physical environment in Conversations between People who are Communication Valunerable and health-care professionals: A Scoping Review. Disability and Rehabilitation, Vol 39(25) pp 2594-2605. Retrieved from http://dx.doi.org/10.1080/09638288.2016.1239769

Yusof, A. N. M. M., \& Rahmat, N. H. (2020). Communication barriers at the workplace: A case study. European Journal of Education Studies, 7(10).

https://oapub.org/edu/index.php/ejes/article/view/3299 